\title{
PENGARUH ORIENTASI PASAR TERHADAP NILAI INOVASI, KEUNGGULAN BERSAING DAN KINERJA PERUSAHAAN
}

\author{
Hanif Mauludin
}

\author{
STIE MALANGKUCECWARA \\ Email: hanif@stie-mce.ac.id
}

Abstrak

Pemasaran yang berorientasi pasar merupakan aktivitas pemasaran yang memberikan perhatian pada pelanggan, pesaing dan kolaborasi unit kerja didalam perusahaan yang sangat diperlukan didalam meningkatkan nilai inovasi untuk membangun keunggulan bersaing yang akan berdampak pada kinerja perusahaan. Penelitian ini bertujuan menguji sejauhmana pengaruh orientasi pasar, nilai inovasi dan keunggulan bersaing terhadap kinerja perusahaan. Penelitian dilakukan pada perusahaan yang bergerak dibidang jasa keuangan. Hasil penelitian menunjukkan bahwa orientasi pasar berpengaruh terhadap nilai inovasi dan keunggulan bersaing. Orientasi pasar tidak berpengaruh secara langsung terhadap kinerja perusahaan. Nilai inovasi dan keunggulan bersaing merupakan variabel yang intervening yang memediasi pengaruh orientasi pasar terhadap kinerja perusahaan.

Kata kunci:orientasi pasar, nilai inovasi, keunggulan bersaing, kinerja perusahaan.

Abstract

Market orientation is the marketing activities that focus on customers, competitors and collaborative work units within the company. These three components are very important in increasing the value of innovation to build competitive advantage that will have an impact on company performance.This study aims to examine the extent of the influence of market orientation, the value of innovation and competitive advantage on the company's performance. The study was conducted on a company engaged in financial services. The results showed that the effect of market orientation on value innovation and competitive advantage. Market orientation has no direct influence on the performance of the company. Value of innovation and competitive advantage is an intervening variable that mediates the effect of market orientation on business performance.

Keywords: market orientation, value of innovation, competitive advantage, firm perfomance 